\title{
Water Crisis in Petorca Basin, Chile: The Combined Effects of a Mega-Drought and Water Management
}

\author{
Ariel A. Muñoz 1,2,*, Karin Klock-Barría 1,2, Camila Alvarez-Garreton 2,3®), \\ Isabella Aguilera-Betti ${ }^{1,4}{ }^{\circledR}$, Álvaro González-Reyes ${ }^{5}$, José A. Lastra $\left.{ }^{6}{ }^{(}\right)$, Roberto O. Chávez ${ }^{6}{ }^{\circ}$, \\ Pilar Barría ${ }^{7}$, Duncan Christie ${ }^{2,3,8}$, Moises Rojas-Badilla ${ }^{1,8}$ and Carlos LeQuesne ${ }^{3,8}$ \\ 1 Laboratorio de Dendrocronología y Estudios Ambientales, Instituto de Geografía, Pontificia Universidad \\ Católica de Valparaíso, Avenida Brasil 2241, Valparaíso 2390302, Chile; karin.klock@pucv.cl (K.K.-B.); \\ isabella.aguilera@pucv.cl (I.A.-B.); moisese.rojasbadilla@gmail.com (M.R.-B.) \\ 2 Center for Climate and Resilience Research (CR)2, Santiago 8340589, Chile; \\ calvarezgarreton@gmail.com (C.A.-G.); duncanchristieb@gmail.com (D.C.) \\ 3 Instituto de Conservación, Biodiversidad y Territorio, Universidad Austral de Chile, Valdivia 5090000, Chile; \\ carlos.lequesne@gmail.com \\ 4 Centro Transdisciplinario de Estudios Ambientales y Desarrollo Humano Sostenible (CEAM), Universidad \\ Austral de Chile, Valdivia 5090000, Chile \\ 5 Hémera Centro de Observación de la Tierra, Escuela de Ingeniería Forestal, Facultad de Ciencias, \\ Universidad Mayor, Santiago 8340589, Chile; alvaro.gonzalez@umayor.cl \\ 6 Laboratorio de Geo-Información y Percepción Remota, Instituto de Geografía, Pontificia Universidad \\ Católica de Valparaíso, Valparaíso 2390302, Chile; jose.lastra@pucv.cl (J.A.L.); \\ roberto.chavez@pucv.cl (R.O.C.) \\ 7 Facultad de Ciencias Forestales y de la Conservación de la Naturaleza, Universidad de Chile, \\ Santiago 8340589, Chile; pili.barria@gmail.com \\ 8 Laboratorio de Dendrocronología y Cambio Global, Facultad de Ciencias Forestales y Recursos Naturales, \\ Universidad Austral de Chile, Valdivia 5090000, Chile \\ * Correspondence: ariel.munoz@pucv.cl; Tel.: +56-32-2274082
}

Received: 4 February 2020; Accepted: 19 February 2020; Published: 28 February 2020

\begin{abstract}
Since 2010, Chile has experienced one of the most severe droughts over the last century, the so-called mega-drought (MD). The MD conditions, combined with intensive agricultural activities and the current water management system, have led to water scarcity problems in Mediterranean and Semi-arid regions of Chile. An emblematic case is the Petorca basin, where a water crisis is undergone. To characterize this crisis, we analyzed water provision by using tree-ring records, remote sensing, instrumental data, and allocated water rights within the basin. Results indicate that the $\mathrm{MD}$ is the most severe dry period over the last 700-years of streamflow reconstruction. During the MD, streamflow and water bodies of the upper parts of the basin have been less affected than mid and low areas of this valley, where consumptive withdrawals reach up to $18 \%$ of the mean annual precipitation. This extracted volume is similar to the MD mean annual precipitation deficits. The impacts of the current drought, along with the drier climate projections for Central Chile, emphasize the urgency for faster policy changes related to water provision. Climate change adaptation plans and policies should enhance the current monitoring network and the public control of water use to secure the water access for inhabitants and productive activities.
\end{abstract}

Keywords: drought; conflicts for water; streamflow reconstruction; water access; water scarcity; water management; climate change 


\section{Introduction}

Chile is amongst the countries with highest risks of being affected by water stress in America [1]. Also, due to the effects of climate change, an increase in extreme drought events is projected for the country, especially for the second half of the 21st century [2]. Due to Chile's condition of high vulnerability to climate change [3], important impacts on agriculture and rural communities are expected [4-6], with economic and social environmental losses that could reach $1.1 \%$ of national gross domestic product (GDP) by the year 2100 [7].

Starting in 2010 and up to date, a mega-drought (MD) has affected Central Chile (CC, 32-37 ${ }^{\circ}$ ), with a persistent multi-year condition that has been assessed as unusual in the context of the last century [8]. Approximately $25 \%$ of this climatic condition has been attributed to anthropogenic climate change [9]. Central Chile, characterized by a semi-arid climate, where most of the population lives [10] and most of the agriculture is developed [11], is also considered the most affected area by the MD. Garreaud et al. [8] indicate that this MD could be considered as an advance of the future climate conditions in Chile, as model-based projections do not show a significant recovery of the mean annual precipitation over the following decades [12].

Regarding water resources management, the water allocation system in Chile is regulated by a water use rights market, where water rights are initially assigned by the estate to private users, in perpetuity and at no cost. Private owners can trade their water rights at pricings following market rules. Under this system, public regulatory and supervisory mechanisms are quite limited [13], which has increased the inequalities in water accessibility [14,15].

The unprecedented MD conditions, combined with intensive irrigated agriculture and the current water management system, have led to water scarcity problems in different locations of Central Chile. In particular, the Petorca river basin (between $32^{\circ}$ and $32^{\circ} 20^{\prime} \mathrm{S}$ ) has been critically affected by water supply shortages. With a population of around 10,000 inhabitants and localities predominantly rural, this basin is considered highly vulnerable to natural disturbances and anthropic activities involving water consumption [16,17]. Agriculture is the main sector in water consumption within the basin [18], an activity that coexists with other economic activities, such as small mining, goat farming, subsistence agriculture, recreation areas and populated centers [19]. During the last decades, an intense advance on fruit plantation has been developed [17], with avocado and citrus fruits as the main planted items [20].

The Petorca river flow has undergone a general reduction during the last decades, reaching zero flow in some sections and leaving the riverbed dry for years [20,21]. This has led to a water crisis, characterized by water access problems, reductions of agricultural productivity, including avocado and other fruit crops, and potential ecological damages [17,22]. Unlike most headwater basins with intensive agriculture in Central Chile, the Petorca basin does not have glaciers in its Andean mountain section. Therefore, water availability within the basin depends exclusively on precipitation and snowfall in winter. This basin was declared a Restriction Area in April 1997 and then declared a Prohibition Area in July 2018, because the levels of extraction surpass the long term sustainable water supply [23].

The Petorca water crisis has become an iconic case of water access inequalities, with contradictions between the water management system and the socio-ecological system [17,24], and violation of water access human rights [25-27]. This crisis has revealed critical flaws in the current water management system. In order to improve the allocation system, a better understanding of the historical water variability in the territory, and a more detailed assessment of drought effects on ecosystems and water resources are necessary [28].

Addressing this challenge, we analyze the multi-year MD in Petorca basin by focusing on different time and spatial scales. We aim at providing a robust diagnostic of the combined MD and water management effects on hydrologic response within the Petorca basin. First, we assess how unusual has been the river flow in the basin during the MD with respect to long-term hydroclimatic variability. Up to date, the long-term historical characterization of the MD has only been done with respect to meteorological conditions (i.e., analyzing precipitation reconstructions). In this work, we complement 
previous studies by analyzing a multi-centennial streamflow reconstruction of the Petorca river developed using tree-rings records. Then, we analyze the historical allocation of water rights within the basin over the last decades and relate them with water supply in different sections of the basin. To further characterize the spatial patterns of the MD effects within the basin, we analyze data from irrigation dams and natural lagoons retrieved from satellite imagery. The analysis of this pool of multi-scale evidences provides information to support water planning for climate change adaptation in Chile.

\section{Data and Methods}

\subsection{Study Area}

The Petorca River basin $\left(32^{\circ} 23^{\prime} 14^{\prime \prime} \mathrm{S} 71^{\circ} 22^{\prime} 31^{\prime \prime} \mathrm{W}\right)$ is located in a transition zone from a Semi-Arid to a Mediterranean climate. The basin covers an area of $1.986 \mathrm{~km}^{2}$, extending around $90 \mathrm{~km}$ from the Andes mountain range to the coast, with an average width of $20 \mathrm{~km}$ [29] (Figure 1). It is born at $3.880 \mathrm{~m}$ above sea level, with two main tributaries, Sobrante and Pedernal rivers, which join to create the Petorca River. Water use within the basin is dominated by agricultural crops, which is consistent with the abundant number of irrigation channels for such a small watershed $[29,30]$.

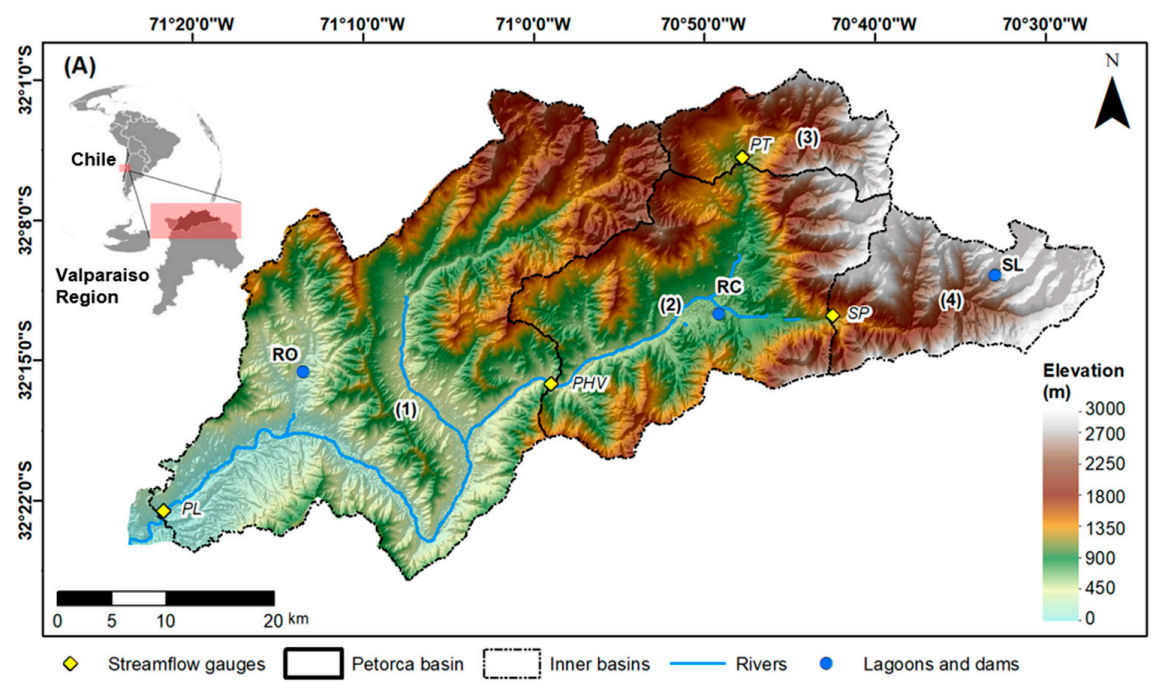

(B)

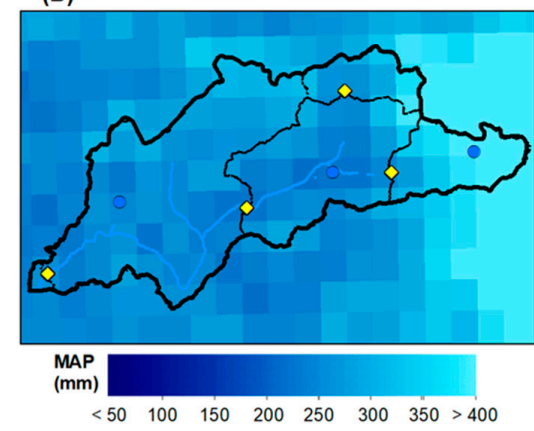

(C)

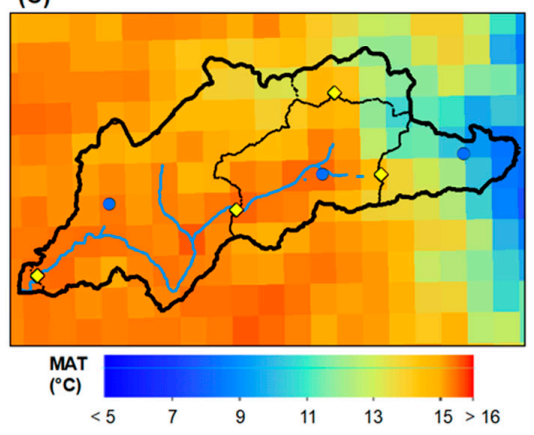

Figure 1. (A) Study area comprising the Petorca basin and its four sub-basins: (1) Petorca river-Longotoma, (2) Petorca river-Hierro Viejo, (3) Pedernal river-Tejada and (4) Sobrante river-Piadero. Location of streamflow gauges (yellow) and water bodies (blue) considered in this study are also shown where PL = Petorca en Longotoma, PHV = Petorca en Hierro Viejo, SP = Sobrante en Piadero, PT = Rio Pedernal en Tejada while RO = reservoir Ossandon brook, $\mathrm{RC}=$ reservoir Colorado brook, $\mathrm{SL}=\mathrm{El}$ Sobrante lagoon. (B) Mean annual precipitation $(\mathrm{mm})$ and $(\mathbf{C})$ mean annual temperature $\left({ }^{\circ} \mathrm{C}\right)$ for the period 1979-2016 obtained from CR2MET [31]. 


\subsection{Streamflow Reconstruction}

The streamflow records selected for the reconstruction was Sobrante en Piadero (32 $13^{\prime} 30^{\prime \prime} \mathrm{S}$ $70^{\circ} 42^{\prime} 43.2^{\prime \prime} \mathrm{W}$ ), located in the upper part of the Petorca Basin (Figure 1) and classified by [32] as a basin with a low human intervention degree (i.e., considered here as a natural basin). The period used for the reconstruction were the months January to May, period with the lowest flow during the year, and thus the most affected by water stress. A stepwise multiple regression model was used to reconstruct the Sobrante river streamflow using tree-ring records (Table 1). For the reconstruction only one predictor was used, a tree-ring chronology named El Asiento (32 $39.073^{\prime}$ S, $70^{\circ} 48.857^{\prime} \mathrm{O}$ ) (Figure 1), located $50 \mathrm{Km}$ south of Sobrante en Piadero, being the only one able to provide a multi centennial ring-width record in proximal regions.

Table 1. Characteristics of the tree-ring data used for the Petorca basin streamflow reconstruction.

\begin{tabular}{cccccc}
\hline $\begin{array}{c}\text { Site Name and } \\
\text { Code }\end{array}$ & Coordinates & Elevation & Dating & $\begin{array}{c}\text { Tree Ring } \\
\text { Series }\end{array}$ & $\begin{array}{c}\text { Series } \\
\text { Intercorrelation }\end{array}$ \\
\hline $\begin{array}{c}\text { El Asiento } \\
\text { (ELA) }\end{array}$ & $\begin{array}{c}32^{\circ} 39.073^{\prime} \mathrm{S}, \\
70^{\circ} 48.857^{\prime} \mathrm{W}\end{array}$ & $1700-1900$ & $451-2017$ & 222 & 0.691 \\
\hline
\end{tabular}

The explained variance between observed and predicted values was assessed by the coefficient of determination adjusted for loss of degrees of freedom $\left(\mathrm{R}^{2} \mathrm{adj}\right)$. We computed the reduction of error (RE) statistics $[33,34]$ to account for the relationship between the actual value and its estimate. The root mean square error (RMSE; [35]) and the Durbin-Watson test (DW [36]) were used to assess the robustness of the reconstruction $[37,38]$.

In order to detect changes in extreme streamflow years within the reconstruction, and analyze the potential changes in the recurrence of dry years similar in magnitude to the year which compound the MD period, we estimated for the entire reconstruction the recurrence rate of drought and pluvial events utilizing a kernel estimation technique with a Gaussian function and 50-year bandwidth. This procedure allows for detection of nonlinear and nonmonotonic trends without imposing parametric restrictions, and a smooth kernel function produces more realistic estimation of low and high discharge events. We calculated a confidence interval at the $95 \%$ level based on 1000 bootstrap resampling steps [39] to estimate bias and variance properties of low and high flow recurrence intervals in the reconstruction. The kernel estimation, bandwidth selection, and bootstrap algorithm were computed in the free R Project platform software [40]. The Kernel estimation was computed using the 20th percentile and 80th percentile as threshold on the variability of the streamflow reconstruction. The Multi-Taper Method (MTM; [41]) was used to identify significant cycles that explained proportions of common variance between the instrumental and reconstructed streamflow records. Additionally, in order to assess the occurrence of low and high streamflow event, we calculated the moving average of the flow anomaly, considering 1, 5, and 10 consecutive years, and ranked them (from 1 to 5) to identify the five highest and five lowest runoff periods. The length of the analyzed windows was defined to provide a wider context for the occurrence of droughts and pluvial events of different durations.

\subsection{Hydrology and Water Allocation}

Hydrometeorological data, including streamflow records, catchment scale precipitation and temperature, and granted water rights within the basins defined by the four streamflow gauges located within the Petorca basin (Figure 1), were obtained from CAMELS-CL dataset [32]. Table 2 shows the main characteristics of each sub-catchments in the Petorca basin. 
Table 2. Characteristics of the four studied catchments in the Petorca Basin used for hydrological analyses.

\begin{tabular}{cccccc}
\hline Name & Area km $\mathbf{~ k m}^{2}$ & $\begin{array}{c}\text { Outlet } \\
\text { Elevation } \\
\text { m a.s.l. }\end{array}$ & $\begin{array}{c}\text { Catchment Mean } \\
\text { Elevation } \\
\text { m a.s.l. }\end{array}$ & $\begin{array}{c}\text { Mean Slope } \\
\mathbf{m} / \mathbf{k m}\end{array}$ & $\begin{array}{c}\text { Annual } \\
\text { Precipitation } \\
\text { mm }\end{array}$ \\
\hline Petorca en Longotoma & 1969.5 & 9 & 1296 & 206.3 & 285 \\
Petorca en Hierro Viejo & 947.2 & 412 & 1782 & 216.1 & 304 \\
Pedernal en Tejada & 56.1 & 1454 & 1625 & 186.4 & 284 \\
Sobrante en Piadero & 241.1 & 1312 & 2610 & 226.2 & 389 \\
\hline
\end{tabular}

To explore the relation between surface water supply and water allocation within the basin, we first characterized the mean response of different sections of the catchment to climatic conditions. This was done by analyzing the hydrologic regimes at different elevations, and by computing annual rainfall-runoff coefficients (ratio of annual runoff to annual precipitation) for each sub-basin. Annual rainfall-runoff coefficients represent how the different parts of the catchment respond to precipitation.

Then, we compare the temporal changes of streamflow records and the water rights granted in the high, mid and low elevations of the basin. To explore whether the catchment runoff generation has been affected by water extractions, we relate the annual rainfall-runoff coefficients with the total volume of granted surface and groundwater rights for the corresponding years.

\subsection{Time Series of Water Bodies Surface Area from Landsat Data}

We used the entire 1986-2019 Landsat satellite catalog to study temporal changes in area of the main water bodies area of our study area (Figure 1): the Ossandon brook reservoir (RO), the Colorado brook reservoir (RC), and the Sobrante lagoon (SL). Landsat imagery has $30 \mathrm{~m}$ spatial resolution and a revisit period of 16 days. Specifically, we used atmospherically corrected Landsat Surface Reflectance (SR) data from Landsat 5 and 8, Collection 1 Tier 1 corresponding to the highest radiometric and positional quality, with precision terrain processing and inter-calibration across the Landsat sensors. A total of 1890 scenes from three Path/Rows (001/082-233/082-233/083) were analyzed covering the three water bodies of the Petorca basin. The analysis was developed in Google Earth Engine (GEE), a cloud-based platform for planetary-scale geospatial analysis [42]. Based on the Landsat quality flags, we remove all pixels flagged as clouds, clouds shadows, or other atmospheric artifacts, following the Landsat 8 and Landsat 4-7 Surface Reflectance Product Guide, available at the USGS Earth Explorer portal [43]. For water body delineation, we calculated the Normalized Difference Water Index [44] using the spectral bands of the Landsat images and identified pixels corresponding to water by simple thresholding ( $>0.01 \mathrm{NDWI}$ ). Landsat scenes where the water bodies were completely or partially covered by clouds were neglected. Finally, we calculated the area per date to construct a time series of the area for the three water bodies.

\section{Results}

\subsection{Multi-Year Mega-Drought in a Multi-Centennial Context}

The streamflow reconstruction using El Sobrante en Piadero gauge is presented in Figure 2. Our reconstruction was able to capture more than $55 \%$ of the total variance using the instrumental record $\left(R^{2}\right.$ adj $=0.56$, Figure 2a). Spectral properties expose significant cycles between 2 and 6 years of periodicity detected in our reconstructed and instrumental streamflow time series. Two significant cycles between 10 and 17 years were also found in the reconstructed record, demonstrating than inter-annual and inter-decadal modes control the discharge dynamics in the Petorca basin (Figure $2 b$ ). On the other hand, our reconstruction presents a clear long-term streamflow reduction from 1830 to present days, with high peak flows only observed prior to 1950 (Figure 2c). However, we identified that the MD period is the driest 5-year period of the entire reconstruction (Table 3). 

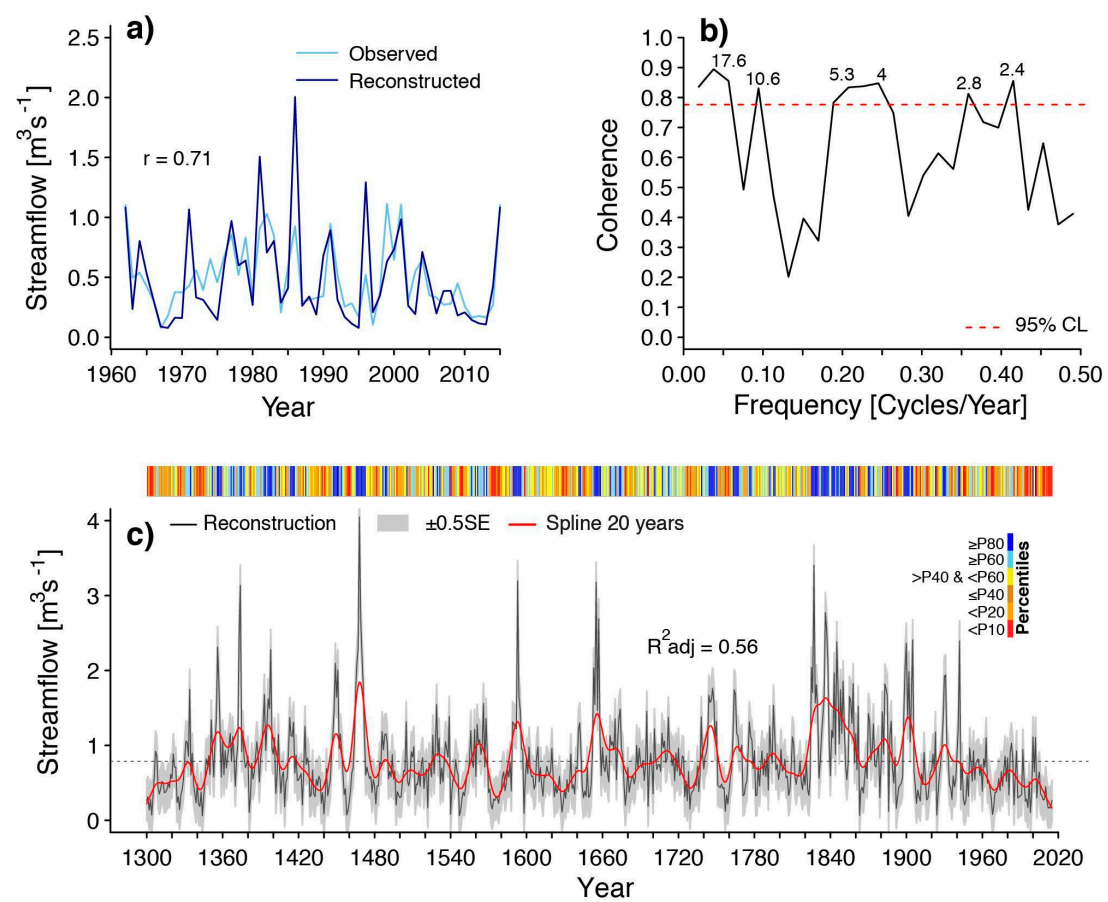

Figure 2. Annual streamflow reconstruction of Sobrante River using tree-ring records. (a) Calibration period of the reconstruction model, (b) Cycles found in the reconstruction using Multi-Taper Method (MTM) analysis, (c) Streamflow reconstruction (1300-2017) of the Sobrante river and its percentiles representations in colors over the reconstruction. The grey band indicates the standard error (SE) as measures of uncertainty. The variance explained was evaluated by the $\mathrm{R}^{2}$ adjusted $=0.562$. The model skills was tested by the Reduction Error $\mathrm{RE}=0.53$, and the residuals of the regression models are normally distributed and not significantly autocorrelated, according to Durbin-Watson tests DW $=1.97$.

Table 3. Ranking of the five extreme annual, 5 year and 10 year periods of low and high streamflow for the Sobrante river streamflow reconstruction.

\begin{tabular}{|c|c|c|c|c|c|c|c|c|c|c|c|}
\hline \multicolumn{4}{|c|}{ Annual } & \multicolumn{4}{|c|}{ Quinquennial } & \multicolumn{4}{|c|}{ Decadal } \\
\hline \multicolumn{2}{|c|}{ Low } & \multicolumn{2}{|c|}{ High } & \multicolumn{2}{|c|}{ Low } & \multicolumn{2}{|c|}{ High } & \multicolumn{2}{|c|}{ Low } & \multicolumn{2}{|c|}{ High } \\
\hline Year & {$\left[\mathrm{m}^{3} / \mathrm{s}\right]$} & Year & {$\left[\mathrm{m}^{3} \mathrm{~s}^{-1}\right]$} & Period & {$\left[\mathrm{m}^{3} \mathrm{~s}^{-1}\right]$} & Period & {$\left[\mathrm{m}^{3} \mathrm{~s}^{-1}\right]$} & Period & {$\left[\mathrm{m}^{3} \mathrm{~s}^{-1}\right]$} & Period & {$\left[\mathrm{m}^{3} \mathrm{~s}^{-1}\right]$} \\
\hline 1344 & 0.0575 & 1468 & 4.0499 & $2011-2015$ & 0.2068 & $1466-1470$ & 2.6681 & 2006-2015 & 0.2716 & 1463-1472 & 1.9753 \\
\hline 1547 & 0.0614 & 1827 & 3.4060 & 1300-1304 & 0.2126 & $1653-1657$ & 2.1828 & 1570-1579 & 0.2917 & 1836-1845 & 1.6650 \\
\hline 1863 & 0.0639 & 1593 & 3.1976 & $1341-1345$ & 0.2313 & $1825-1829$ & 2.1049 & $1337-1346$ & 0.3237 & $1897-1906$ & 1.5509 \\
\hline 1304 & 0.0680 & 1655 & 3.1801 & $1547-1551$ & 0.2378 & $1834-1838$ & 2.0941 & $1622-1631$ & 0.3545 & $1652-1661$ & 1.5224 \\
\hline 1924 & 0.0697 & 1374 & 3.1381 & $1456-1460$ & 0.2432 & 1898-1902 & 1.8331 & 1965-1974 & 0.3653 & $1588-1597$ & 1.3674 \\
\hline
\end{tabular}

In Table 3 we summarize the ranking of the extreme events for one single year, and periods of five and ten years. Notably, the reconstruction shows that during the last seven-hundred years, the river bed never went dry in the upper part of the Petorca basin.

From the analysis of the extreme events (Table 3), we found that none of the MD years classify as extreme low single-year. No high single year peak was also recorded within the last century. According to the results presented in Table 3, the 5-year and 10-year lowest dry spells on record correspond to the MD years, which are only followed by the 1570-1579 and the 1337-1346 10-years droughts (Table 3).

The percentiles (Figure 2) and the ranking of extreme values (Table 3) illustrate the unusualness of the MD period, corroborating the tight range of water availability that the Petorca basin is currently facing.

In order to evaluate changes in the occurrence rate of water extremes, we calculated the occurrence rate given by a kernel-based estimation (see Methods). The results are displayed in Figure 3, identifying that low flows increase to the present, contrary to the high peak flows. The drought occurrence rate 
has become more frequent to present days, from a long-term mean value around 6 years (average of the last centuries), to values around 2 years in the present (Figure 3).

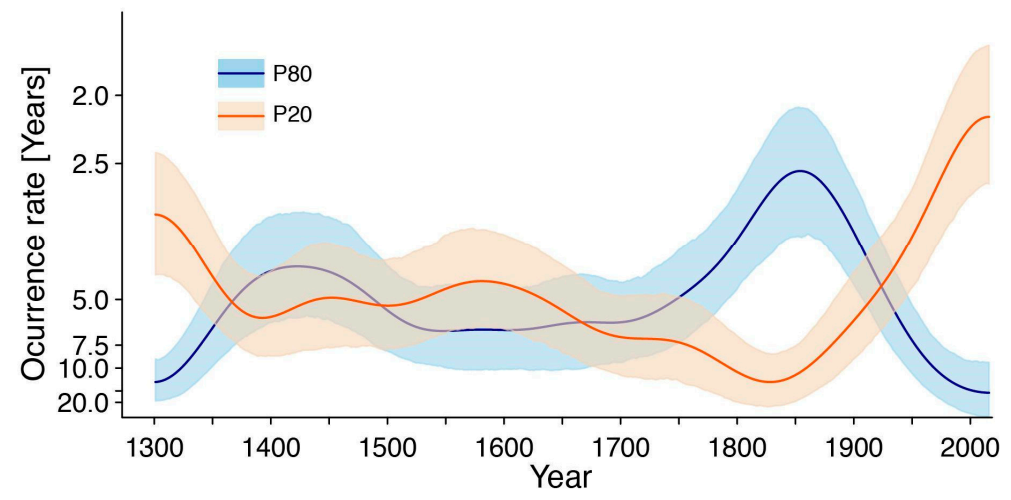

Figure 3. Changes in the occurrence rate of water extreme events based on the streamflow reconstruction, and calculated for the period $1300-2015$. The 20th percentile $\left(0.38 \mathrm{~m}^{3} \mathrm{~s}^{-1}\right)$ was used to identify dry years, while for wet years the 80 th percentile value threshold $\left(1.07 \mathrm{~m}^{3} \mathrm{~s}^{-1}\right)$ was used. The confidence band at $95 \%$ confidence level is shown around the Kernel-based curves, and was obtained using 1000 bootstrap simulations.

\subsection{Hydrological Response over the Last Decades}

In Figure 4 we show the hydrologic regimes of the study basins, with mean monthly values of basin-averaged precipitation, basin-averaged temperature and runoff (streamflow normalized by basin area). The upstream part of the catchment, defined by the Sobrante en Piadero stream gauge, with higher elevations, higher precipitation and lower temperatures (Figure 4a,b), is mainly dominated by snowmelt processes. On the other hand, the lower parts of the catchment are mainly dominated by pluvial processes (Figure 4c).
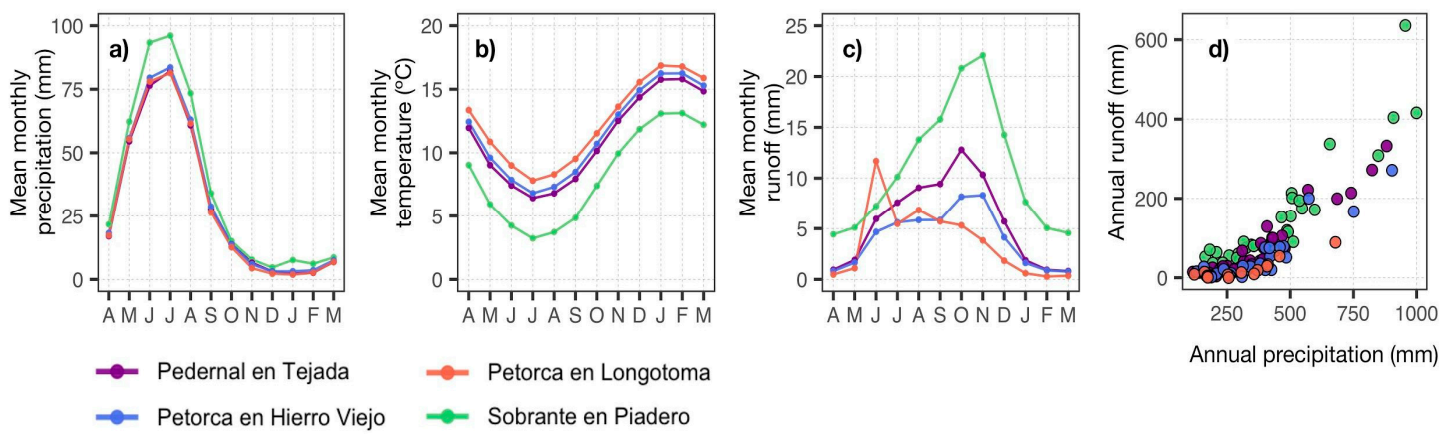

Figure 4. Hydrologic regimes within Petorca basin. (a) Mean monthly precipitation, (b) mean monthly temperature, and (c) mean monthly runoff for the four sub-catchments. Panel (d) shows the annual rainfall-runoff relationship for each sub-basin.

The plot in Figure 4d indicates that, for a same amount of annual precipitation, streamflow at the catchment outlet is significantly lower in the downstream gauges, which is consistent to the higher water consumption towards mid and lower parts of the basin, where population and agricultural lands are located.

Complementing the long-term historical context provided in Section 3.1, Figure 5 illustrates the evolution of hydro-meteorological variables within the Petorca basin over the last 4 decades, where the MD starting in 2010 stands out with its prolonged precipitation deficits and high temperatures, which in turn leads to extremely low runoff across the complete Petorca basin. 

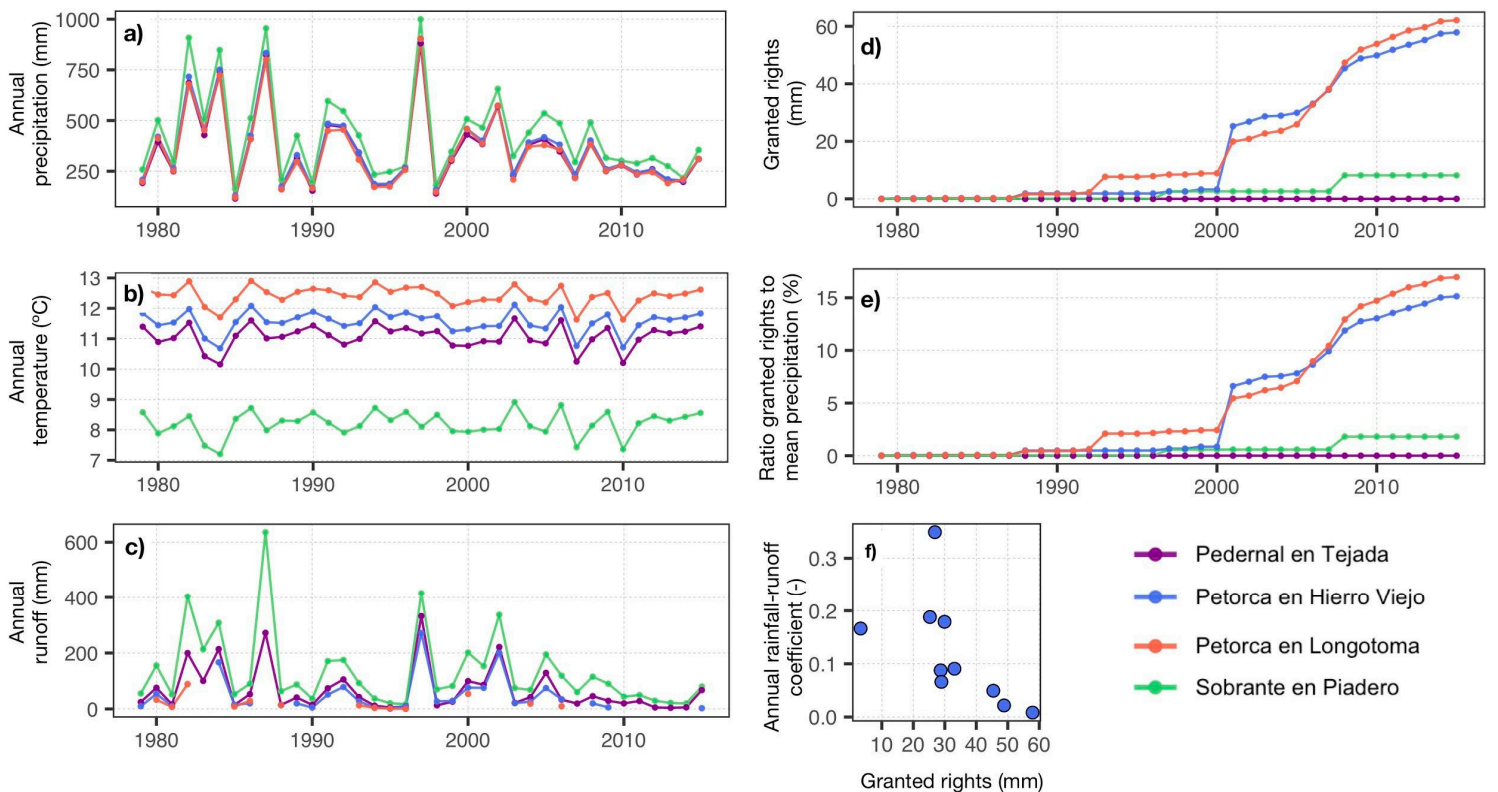

Figure 5. Time series of hydro-meteorological variables: (a) Annual precipitation, (b) annual temperature and (c) annual runoff for each sub-catchment. Panel d shows the volume of accumulated granted rights (both surface and groundwater rights) and panel e shows the same volumes normalized by mean annual precipitation of the corresponding sub-basin. To make them comparable with precipitation and runoff, we normalized the annual granted volume (d) and (e) by the corresponding catchment area. Panel (f) shows the annual rainfall-runoff coefficient (annual runoff normalized by annual precipitation) related to the accumulated volume of granted rights for the corresponding year for Petorca en Hierro Viejo sub-basin.

Although climatic conditions directly affect runoff generation, water use within the basin also affects the available water at the river. To illustrate this, we present the evolution of water allocation within Petorca. The plots in Figure 5d shows that water allocation started around 1990 in the lower part of the catchment (Petorca en Longotoma) and in 2000 in the middle part (Petorca en Hierro Viejo), consistently increasing up to date, reaching up to $18 \%$ of the mean annual precipitation of the catchment (Figure 5e).

To explore how the water allocation may affect streamflow generation, Figure $5 \mathrm{f}$ presents the annual runoff coefficients (a good indicator of 'catchment water productivity') as a function of granted water rights at one of the downstream gauges. Based on the allocation dates within the Petorca en Hierro viejo catchment (Figure 5d), only years after 2000 are plotted. There is a high correlation between allocated water and water availability at the river stations (significant decrease in runoff generation from a given precipitation, for larger volumes of allocated water), which is expected given the associated higher agricultural-induced evapotranspiration rates.

Finally, the comparison of the water bodies in the basin, including natural lagoons and small dams, shows the highest area reduction in the RO dam, located in the lower part of the basin (Figure 6c), followed by the RC dam which was a little less affected by area reduction during MD (Figure 6b), and an almost non apparent reduction during the MD in the high elevation natural lagoon (SL) analyzed (Figure 6a). In the three water bodies the summer season shows lowers areas, which is especially clear in the case of the RC and RO dam, located in the mid and low section of the basin, respectively (Figure 6). 
(a)

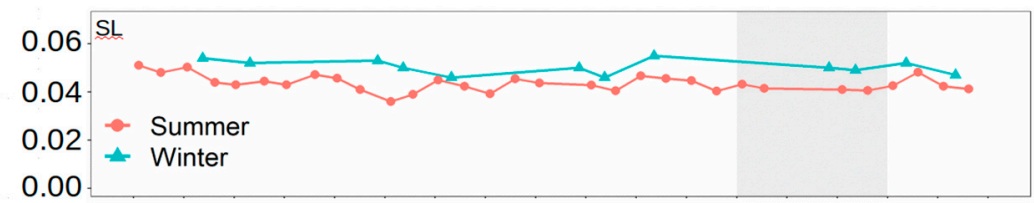

(b)

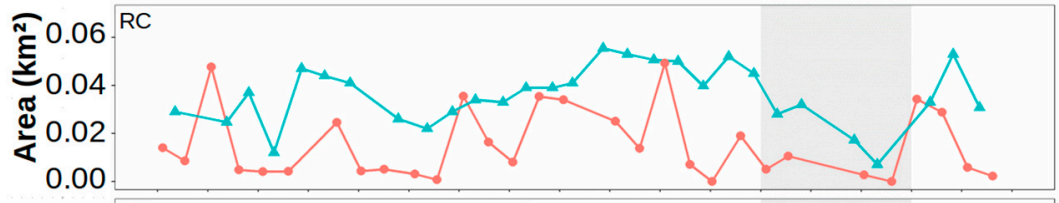

(c)

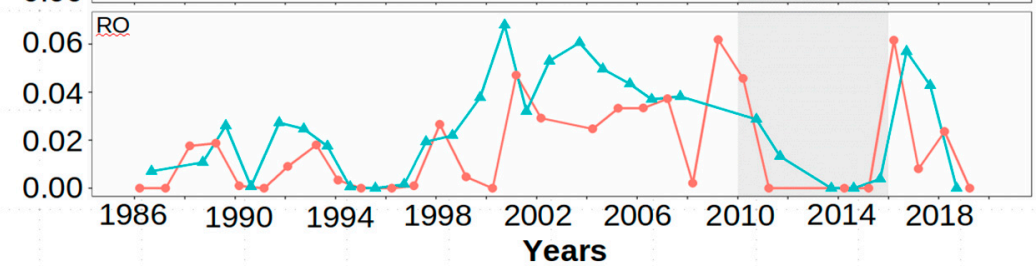

Figure 6. Mean winter (June-July-August) and summer (January-February-March) area of the three main water bodies of the Petorca basin between 1986 and 2019, for (a) El Sobrante lagoon (SL), (b) Colorado brook dam (RC), and (c) Ossandon brook dam (RO). Shaded area corresponds to the MD period.

\section{Discussion}

\subsection{The 700 Years of Petorca River Streamflow Reconstruction and the Current MD}

The present work exposes the Petorca river reconstruction spanning the years 1300-2015, the longest streamflow reconstruction of South America at present day. This reconstruction offers a new long-term perspective for the entire Mediterranean region in Chile. A relevant feature of our reconstruction is the retained variance, having the highest explained variance of any streamflow reconstruction in South America (56\% of total variance), and contrasting previous river reconstructions carried out in several South American rivers by authors as: Mundo et al. [45], Lara et al. [46,47], Urrutia et al. [48], Ferrero et al. [49], Muñoz et al. [37], Barria et al. [13,50], and Fernandez et al. [51]. In statistical terms, the RE of the reconstruction was 0.53 considered good and a little higher than the other streamflow reconstructions in South America. This calibration statistic was assessed as a rigorous measure of the relationship between observed and estimated values. The theoretical limits of the RE range from a maximum of 1 to negative infinity. Any positive value indicates that the model has some predictive capacity [52,53]. As a measure of reconstruction uncertainty, we computed the root-mean-square error (RMSE), obtaining values within the range of previous reconstruction in Chile [37,51]. Residual autocorrelation was evaluated using the Durbin-Watson test [35]. The Petorca streamflow reconstruction presented values close to 1 , confirming the non-autocorrelation of the residuals.

Even when the Petorca reconstruction exposes cycles associated to periodicities between 2 to 5 and 10 to 17 years, most of the temporal variability is related to El Niño Southern Oscillation (ENSO). Such a strong relation with ENSO was also found in the reconstruction of the Maule river [48], located in central Chile domain. If we compare the relationship between our reconstruction and El Niño 3.4 index from May to September months during 1870-2015, we obtain a significant relationship $(\mathrm{r}=0.30$; $\mathrm{P}<0.001$; Figure S1a). In addition, our results support the idea that ENSO is the most important climate forcing in the Mediterranean region, on an interannual scale. The high influence of ENSO on the hydroclimate of Mediterranean region in Chile, was also identified by González-Reyes et al. [54] analyzing streamflow instrumental records between $30^{\circ}-37^{\circ} \mathrm{S}$. The cycles identified in the Petorca streamflow reconstruction are also similar to the precipitation reconstructions in the Mediterranean region of Chile $[55,56]$ and demonstrate the important influence of ENSO in the hydroclimate of central Chile at different time scales. In this context, the MD stands out by changing the historical pattern of 
higher annual precipitation associated with El Niño phase of ENSO. During the MD, El Niño years have not represented wet years as was the pattern in the past [8]. We support this finding comparing the ENSO variations, given by El Niño 3.4 index, and the Petorca streamflow reconstruction, obtaining a decay in Pearson correlation terms between both variables during the MD using 5 and 7 year periods running mean (Figure S1b). Based on our results, we hypothesize that MD could be related to decadal to multidecadal mechanisms that occurred in the sea surface temperature across the Pacific Ocean. A current study performed by Garreaud et al. [12] shows relations between Central Chile precipitation variability and extra-tropical patterns near New Zealand coasts, within the Pacific Ocean domain.

Regarding the severity of the MD-induced hydrological drought, the streamflow in Petorca headwater basin appears as the driest five-years period of the last seven hundred years. This new long-term hydroclimate record also confirms a higher occurrence of high flows in the river in previous centuries and the climatic absence of these events in the last 170 years, approximately since 1830 (Figure 2c). This period is the beginning of the current decreasing precipitation trend, also described by Le Quesne et al. [55] and Garreaud et al. [8] using precipitation reconstructions. Despite the extremely dry year 2019, that given the timing of this analysis was not included in the reconstruction, one characteristic of the MD is the lack of extreme dry years, confirmed by the absence of extreme low flow years in the extreme events ranking (Table 3). This corroborates previous findings (e.g., [8]), where the MD is described as extraordinary by its multi-year duration rather than by the drought severity of single years. Nonetheless, in both quinquennial and decadal periods of the ranking, the MD has been the driest average low flow of the reconstructed seven hundred years (Table 3).

The current MD unusual climatic phenomenon of consecutive dry years aggravates the increasing pattern of yearly drought recurrence (i.e., low flows) observed since the nineteenth century, which has also been documented for other rivers in South-Central Chile [37,51]. This illustrates the large geographical effects that threatens water supply in diverse types of territories and climates of Chile.

Recent climatic evidence indicates that this low precipitation pattern will continue in the next decades [12], pushing water planning in search of new ways to administer this vital resource. Recently, the intensity of the social conflicts for water in Petorca have transcended the local scale, placing Petorca crisis in a spotlight at national level. In this context, the current exportation and agricultural model, along with the water market model have been criticized, with demands ranging from revisions up to derogation of the Water Code and Constitution [17]. Furthermore, current Chilean social demands include the water law as one of the most important changes required to increase equality in the country.

\subsection{Hydrological Changes, Water Allocation, and Water Crisis}

Hydrological records over the last decades also show important changes, starting in the middle of the twentieth century in most rivers of central Chile, and many other rivers fed by the Andes in South America [57]. As previously stated, the Petorca river recharge is fully dependent of precipitation and snowfall in winter, due to the lack of glaciers in the higher elevations of the basin. The river shows a decrease in streamflow, partly due to the reduction of precipitation in Central Chile [8] and the decreasing trends of snow persistence in the Andes at this latitude [58], and in particular a decreasing trend in snow cover in Petorca [59].

Given the near natural conditions of headwater catchments (SP and PT, Figure 1) in Petorca basin, supported by the absence of granted water rights within those basins (Figure 5d), streamflow deficits in SP and PT during the MD can be exclusively attributed to the meteorological conditions of the MD (consecutive years of lower precipitation and higher temperature). At lower locations however, the changes in hydrology are due to a combination of meteorological conditions and anthropic intervention, particularly, water extractions for irrigated agriculture.

In this way, the low elevation gauges show higher reductions than the gauges located in the upper part of the basin (Figure 5c). Regarding groundwater sources, the water levels recorded at wells located in the mid and low elevations areas of Petorca basin have indicates reductions of up to $300 \%$ during the MD years compared on the water levels of the previous decade [60]. Because of these strong reductions, 
in 2014 the Chilean Water Directorate (DGA) decided to limit water extractions of provisional granted water rights in the Petorca Basin, in order to reduce the water deficit in the area and to lower the impact on permanent water rights. It was established that the reduction corresponded to a permanent deficit and not to temporal effects [23]. From our analysis, we show a clear relation between granted water rights and a higher streamflow reduction within the basin (Figure 5f), where allocated water rights reach up to $18 \%$ of the mean annual precipitation of the catchment (Figure $5 \mathrm{~d}, \mathrm{e}$ ). To put this extraction amount into context, we can assume basins under natural conditions and considering an additional 18\% deficit in MD meteorological conditions. Given that the recorded mean precipitation deficits during the MD in the area are around 20\% [8], adding water extractions implies to double the severity of MD in Petorca. Further, considering the water crisis undergone in the basin, unauthorized surface and groundwater extractions may exists, which would increase these human-induced deficits.

As is discussed by Panes-Pinto et al. [17], the National Institute of Human Rights [20], despite the depletion of water resources in the basin, the DGA granted 1362 water rights in the province of Petorca, most of them underground.

Even when Central Chile is facing unprecedented multi-year precipitation deficits, the water crisis in Petorca appears to be particularly related to water repartition and the location in the basin. This is clear when we analyze water accessibility from social organizations in rural areas (i.e., APR: Agua Potable Rural), where only two out of the twenty APRs in Petorca basin have access to water sources [61] (Figure A1). The most affected communities are those located far away from the river course (Figure A1), deepen even more the territorial inequality to water access. Eleven of these communities need permanent external water supply, four of them receive water intermittently, and other seven communities have frequent interruption in water supply [61].

At present, the Municipality of Petorca has recorded more than 2.000 people depending on water supply by cistern trucks, corresponding to $20 \%$ of the total population of the Petorca basin [61]. These numbers are larger in summer, given the higher water consumption rates from people and agriculture. Consistently, in summer season the dams located in mid and low elevation show an important decrease in the water area associated to the increase in water demand during the MD (Figure 6 b,c), opposite to the high elevation lagoon (SL), which represent near-natural conditions and shows only a slight decrease in its water area (Figure 6a). The extreme reduction of water bodies located in mid and low elevation areas during the MD can be observed from satellite images (Figure A2). The same pattern was reported by Garreaud et al. [8] analyzing one of the biggest water reservoirs used for irrigation in Central Chile (La Paloma Dam). More recently, some of the natural bodies used for irrigation and traditional use by human communities in central Chile have been documented completely dry, as the Aculeo lagoon in the Metropolitan region [62], or the Matanza lagoon in the Valparaiso region [63], confirming the generalized problem of water bodies affected by water scarcity in Chile.

Regarding water management, the water code in Chile has received many critics and woken up opposition from different sectors because of the territorial inequalities that it generates, $[14-18,24,25]$. One of the key problems of this code and the Chilean water management system, is related to the control and inspection of granted water rights. This issue is particularly important in Petorca, a basin declared as depleted in 1997, but where only in 2008 the DGA started to control its water extractions. In the period 2008-2018, the DGA has received 241 formal complains about illegal use of water in Petorca [61]. On the other hand, the National Institute of Human Rights [20], indicate that the DGA has processed around 447 files for illegal extraction of waters only between 2010 and 2014 [17,20]. The rise of the water conflicts has been manifested in "legal protection resources" presented by communities and families of the Petorca basin, most of them related with the impossibility to access drinking water, and many others related with the amount of water received by person in the cistern trucks, in most of the cases less than 100 liters/person/day, which is indicated by the Chilean law as the minimum by person following the World Health Organization (WHO) recommendation [61]. In December of 2019, the Chilean courts emitted the first dictation in favor of 181 people from different communities of Petorca, arguing that the Chilean state has not guaranteeing the minimal water consumption amount 
by person in Petorca [64]. As this case, there are many other legal cases being analyzed by the Chilean courts related with Petorca and other territories in Chile. Some of these cases can be found in webpages such as the Social Water Conflicts Portal [65] and specific literature developed from these environmental issues $[24,26,66,67]$.

Today and as a consequence of massive demonstration claiming for reducing inequalities, the Chilean parliament is discussing laws to create more equal chances for people who use water for different objectives. Two important opportunities arise to achieve this. One instance is the plebiscite to change the constitution, which will occur in April 2020, where the water code and the right to access water for human consumption could be modified. Another instance is the Climate Change project law, which is currently being discussed, where water security is one of the main challenges declared in this project. Further, Chile is currently facing a socio-political crisis, which exploded in October 2019 and has raised social demands including education, health, retirement pension, and the right to water access. Water crisis is thus part of the social crisis, as one of the main topics that the people declare necessary to create a less unequal country.

\section{Conclusions}

The mega-drought (MD) period has been the driest period ever registered in the Petorca basin within the last 700 years, and together with the unsustainable water use rates have propitiated water scarcity conditions and triggered a social water crisis. An urgent response of the national authorities and the local stakeholders to improve the water management is needed in order to provide short- and long-term solutions to the current water crisis and the projected water scarcity. Climate projections for most of the territories located in the subtropical Mediterranean-like climate regions indicate strong precipitation reductions for the following decades [68-70], and the learnings obtained from the analyses of the water crisis experienced in the Petorca basin could be valuable information for regions characterized by an agricultural tradition and similar water management systems, such as south of Africa, Australia, and the California region of the United States, among others. These learnings are particularly relevant under the considerations indicated by the United Nations and the IPCC report on climate change and terrestrial ecosystems [71], which highlighted that is highly likely that the planet will face strong water scarcity by the end of the century.

According to the analyses presented in this article, the unusual low runoff-measured at the Petorca river during the MD cannot be fully explained by the meteorological conditions; the water extractions within the period for intensive agriculture, with the associated higher evapotranspiration rates also play an important role in the water scarcity crisis. Attribution studies based on hydrological models are necessary to disentangle the role of the water consumption by agriculture and human communities, from the climatological factors. This is especially important for climate change adaptation processes to be conducted in Chile and other territories of the world, where the dry signal is very consistent and expected to persist. Therefore, the current MD offers an opportunity for Chile to improve and strengthened the water management policies for the future.

Supplementary Materials: The following are available online at http://www.mdpi.com/2073-4441/12/3/648/s1, Figure S1: Relationship between the Petorca Streamflow reconstruction and El Niño 3.4 index.

Author Contributions: Conceptualization, A.A.M., I.A.-B., K.K.-B. and C.A.-G.; methodology, A.A.M., Á.G.-R., C.A.-G., R.O.C., D.C., P.B. and C.L.; software, J.A.L., C.A.-G., M.R.-B. and Á.G.-R.; formal analysis, K.K.-B., A.A.M., Á.G.-R., C.A.-G., J.A.L., R.O.C. and P.B.; investigation, A.A.M., K.K.-B., I.A.-B. and C.A.-G.; resources, I, A.B., C.L., D.C and A.A.M.; writing-original draft preparation, A.A.M., K.K.-B., Á.G.-R., I.A.-B., M.R.-B. and C.A.-G.; writing-review and editing, A.A.M., K.K.-B., C.A.-G., I.A.-B., P.B., D.C. and R.O.C.; visualization, J.A.L., R.O.C. and Á.G.-R.; supervision, A.A.M. and K.K.-B.; project administration, A.A.M. and I.A.-B.; funding acquisition, A.A.M., D.C. and I.A.-B. All authors have read and agreed to the published version of the manuscript.

Funding: This research was funded by Chilean Research Council, FONDECYT 11161061, 1181956, 3170428 and the Center for Climate and Resilience Research (CR)2, FONDAP 15110009. 
Acknowledgments: A. Muñoz and R. Chavez thank the Research Nucleus in Natural Base Solutions of the Pontifical Catholic University of Valparaiso (PUCV) 39.431/2020. The authors thank the Water Resources Office of the Municipality of Petorca, Chile. This research emerged from the collaboration with many colleagues at the Center for Climate and Resilience Research (CR2, CONICYT/FONDAP/15110009). Camila Alvarez-Garreton is funded by FONDECYT postdoctoral Grant No. 3170428. A. González-Reyes thank to Chilean Research Council, PAI Grant No. 77190101. A. Muñoz, K. Klock-Barría and I. Aguilera-Betti thanks to FONDECYT Grant No. 11161061. C. Le Quesne and D. Christie thanks to FONDECYT Grant No. 1181956. The authors thank to the Corporación Nacional Forestal (CONAF), El Asiento community, and Jonathan Barichivich for helping in the tree-ring research developed in this study.

Conflicts of Interest: The authors declare no conflict of interest. The funders had no role in the design of the study; in the collection, analyses, or interpretation of data; in the writing of the manuscript, or in the decision to publish the results.

\section{Appendix A}

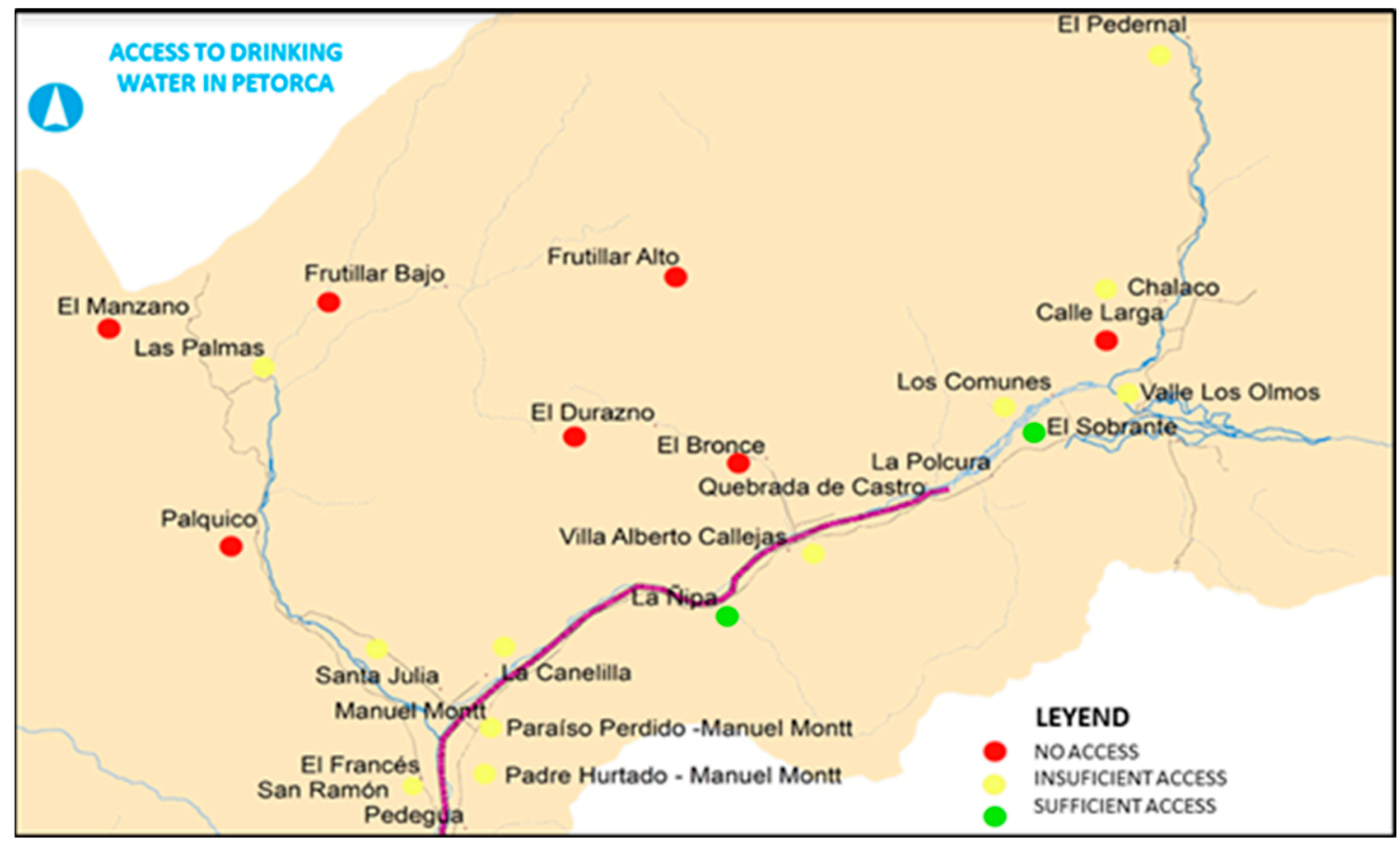

Figure A1. Access to drinking water in Petorca, considering the situation up to December 2019. Source: Water Resources Office, Municipality of Petorca, Chile [61]. 


\section{Appendix B}

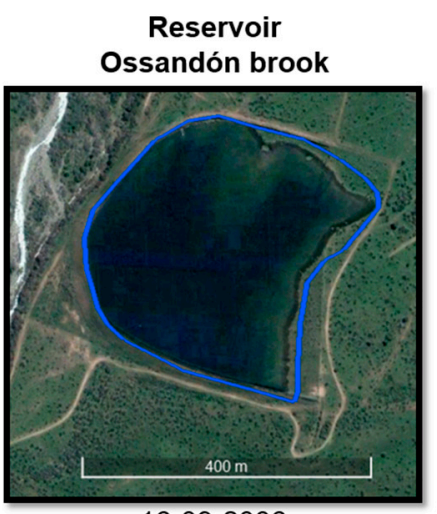

$16-09-2006$

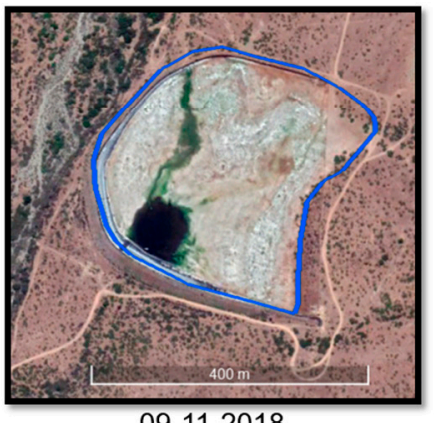

$09-11-2018$

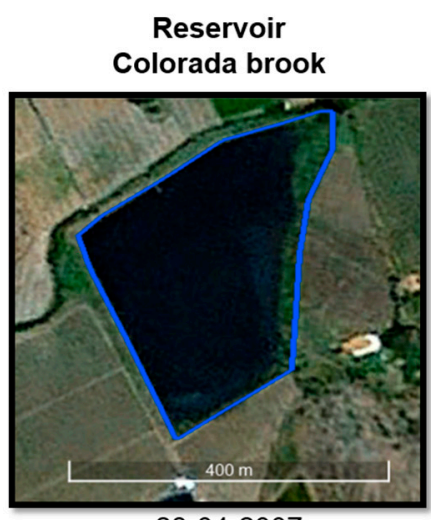

28-04-2007

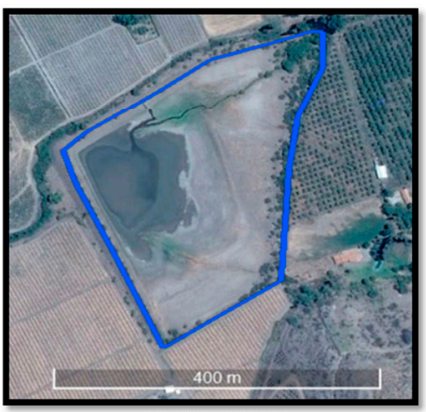

$17-01-2013$
El Sobrante lagoon
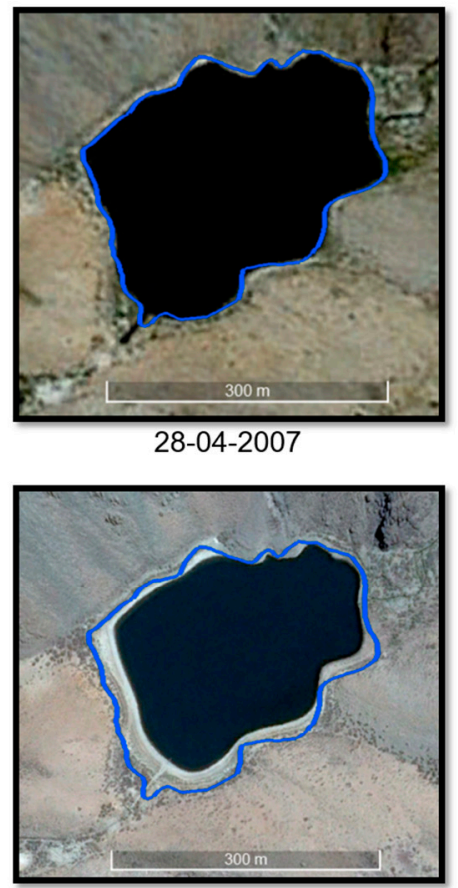

$15-03-2015$

Figure A2. Examples of the dramatic fluctuations in area for the main water bodies of the Petorca basin. Source: Google Earth.

\section{References and Note}

1. WRI. Aqueduct ${ }^{\mathrm{TM}}$ Water Risk Atlas (Aqueduct 3.0). 2019. Available online: https://www.wri.org/aqueduct/ (accessed on 15 January 2020).

2. CEPAL. La economía del cambio climático en Chile: Síntesis. 2009. Available online: https://repositorio. cepal.org/bitstream/handle/11362/32827/1/S2009772_es.pdf (accessed on 5 October 2019).

3. Government of Chile Intended Nationally Determined Contribution of Chile: Towards the Climate Agreement of Paris. 2015. Available online: https://www4.unfccc.int/sites/submissions/INDC/Published\%20Documents/ Chile/1/INDC\%20Chile\%20english\%20version.pdf (accessed on 24 January 2020).

4. Santibáñez, F.; Santibáñez, P.; Solis, L. Análisis de vulnerabilidad silvoagropecuaria en Chile frente a escenarios de Cambio Climático. In Análisis de Vulnerabilidad del Sector Silvoagropecuario, Recursos Hídricos y Edáficos de Chile Frente a Escenarios de Cambio Climático; Centro AGRIMED, Universidad de Chile: Santiago Metropolitan Region, Chile, 2008. Available online: Ftp://dgf.uchile.cl/pub/maisa/SOC28/Capitulo4_Vulnerabilidad_ Silvoagropecuaria/IV\%20-\%20Vulnerabilidad\%20-\%20Informe\%20Final.pdf (accessed on 6 October 2019).

5. Ponce, R.; Blanco, M.; Giupponi, C. The economic impacts of climate change on the Chilean agricultural sector. A non-linear agricultural supply model. Chil. J. Agric. Res. 2014, 74, 404-412. [CrossRef]

6. MMA. Plan de Acción Nacional de Cambio Climático 2017-2022. 2017. Available online: https://mma.gob.cl/ wp-content/uploads/2017/07/plan_nacional_climatico_2017_2.pdf (accessed on 6 October 2019).

7. CEPAL. La economía del cambio climático en Chile. 2012. Available online: https://repositorio.cepal.org/ bitstream/handle/11362/35372/1/S2012058_es.pdf (accessed on 6 October 2019).

8. Garreaud, R.D.; Alvarez-Garreton, C.; Barichivich, J.; Boisier, J.P.; Christie, D.; Galleguillos, M.; LeQuesne, C.; McPhee, J.; Zambrano-Bigiarini, M. The 2010-2015 megadrought in central Chile: Impacts on regional hydroclimate and vegetation. Hydrol. Earth Syst. Sci. 2017, 21, 6307-6327. [CrossRef] 
9. Boisier, J.P.; Rondanelli, R.; Garreaud, R.D.; Muñoz, F. Anthropogenic and natural contributions to the Southeast Pacific precipitation decline and recent megadrought in central Chile. Geophys. Res. Lett. 2016, 43, 413-421. [CrossRef]

10. INE. Compendio Estadístico, Instituto Nacional de Estadísticas. 2017. Available online: www.ine.cl (accessed on 26 February 2020).

11. INE. Censo Agropecuario. 2017b. Available online: www.ine.cl (accessed on 8 October 2019).

12. Garreaud, R.D.; Boisier, J.P.; Rondanelli, R.; Montecinos, A.; Sepúlveda, H.H.; Veloso-Aguila, D. The Central Chile Mega Drought (2010-2018): A climate dynamics perspective. Int. J. Climatol. 2020, 40, 421-439. [CrossRef]

13. Barría, P.; Rojas, M.; Moraga, P.; Muñoz, A.; Bozkurt, D.; Alvarez-Garreton, C. Anthropocene and streamflow: Long-term perspective of streamflow variability and water rights. Elem. Sci. Anth. 2019, 7, 2. [CrossRef]

14. Bauer, C.J. Results of Chilean water markets: Empirical research since 1990. Water Resour. Res. 2004, 40, W09S06. [CrossRef]

15. Hearne, R.; Donoso, G. Water Markets in Chile: Are They Meeting Needs? In Water Markets for the 21st Century. Global Issues in Water Policy; Easter, K., Huang, Q., Eds.; Springer: Dordrecht, The Netherlands, 2014; Volume 11, pp. 103-126. [CrossRef]

16. Budds, J. Power, nature and neoliberalism: The political ecology of water in Chile. Singap. J. Trop. Geogr. 2004, 3, 322-342. [CrossRef]

17. Panez-Pinto, A.; Mansilla-Quiñones, P.; Moreira-Muñoz, A. Agua, tierra y fractura sociometabólica del agronegocio. Actividad frutícola en Petorca, Chile. Bitácora Urbano Territorial 2018, 28, 153-160. [CrossRef]

18. Budds, J. La demanda, evaluación y asignación del agua en el contexto de escasez: Un análisis del ciclo hidrosocial del valle del río La Ligua, Chile. Rev. Geogr. Norte Gd. 2012, 52, 167-184. [CrossRef]

19. DGA. Definición sobre los derechos de aprovechamiento de aguas subterráneas provisionales en las Áreas de Restricción La Ligua y Petorca, Región de Valparaíso. Informe Técnico N70. 2004. Available online: http://documentos.dga.cl/SUB5475.pdf (accessed on 8 October 2019).

20. INDH. Informe misión de observación Provincia de Petorca. 2014. Available online: https://bibliotecadigital. indh.cl/bitstream/handle/123456789/774/Informe.pdf?sequence=1 (accessed on 8 October 2019).

21. Nieto, I.; Velasco, M.; Pohl, N.; Muñoz, G. Water Issues in Chile: How Does a Dry River Sound? Leonardo 2018, 51, 189-190. [CrossRef]

22. Fragkou, M.C.; Budds, J. Desalination and the disarticulation of water resources: Stabilising the neoliberal model in Chile. Trans. Inst. Br. Geogr. 2019, 1-16. [CrossRef]

23. DGA. Informe Técnico: Evaluación del actual nivel de explotación de los acuíferos de La Ligua y Petorca. 2018. Available online: http://documentos.dga.cl/SUB5805.pdf (accessed on 22 November 2019).

24. Panez-Pinto, A.; Faúndez-Vergara, R.; Mansilla-Quiñones, C. Politización de la crisis hídrica en Chile: Análisis del conflicto por el agua en la provincia de Petorca. Agua y Territorio 2017, 10, 131-148. [CrossRef]

25. Guiloff, M.; Mewes, I.; Rivera, R.; Edwards, J. El derecho al agua como un Derecho Humano: El caso de la provincia de Petorca. In Centro de Derechos Humanos, Facultad de Derecho Universidad Diego Portales. Informe anual sobre Derechos Humanos en Chile 2013; Universidad Diego Portales: Santiago de Chile, Chile, 2013. Available online: http://www.derechoshumanos.udp.cl/wp/wp-content/uploads/2013/10/libro_DD_HH_ capitulo7.pdf (accessed on 10 January 2020).

26. Bolados García, P. Conflictos socio-ambientales/territoriales y el surgimiento de identidades post neoliberales (Valparaíso-Chile). Izquierdas 2016, 31, 102-129. [CrossRef]

27. Bolados García, P.; Henríquez Olguín, F.; Ceruti Mahn, C.; Sánchez Cuevas, A. La eco-geo-política del agua: Una propuesta desde los territorios en las luchas por la recuperación del agua en la provincia de Petorca (Zona central de Chile). Revista Rupturas 2018, 8, 167-199. Available online: https://www.scielo.sa.cr/pdf/rup/ v8n1/2215-2989-rup-8-01-159.pdf (accessed on 15 January 2020). [CrossRef]

28. Aguilera-Betti, I.; Muñoz, A.A.; Klock-Barría, K.; Chávez, R.O.; Lastra, J.; González-Reyes, A.; Rojas-Badilla, M. Water availability changes during the 2010-2015 mega-drought in the Petorca basin: Response of agriculture, native vegetation and water access in one of the most drought affected basin of Chile. In Proceedings of the Hidden Geographies International Conference, Ljubljana, Slovenia, 29-31 August 2019.

29. DGA. Evaluación de los Recursos Hídricos Superficiales de las Cuencas de los ríos Petorca y La Ligua, Va Región. 2006. Available online: http://documentos.dga.cl/SUP4496.pdf (accessed on 15 January 2020). 
30. MOP. Actualización Informe Evaluación de los Recursos Hídricos Superficiales de las Cuencas del río Petorca y río La Ligua, Región de Valparaíso. 2013. Available online: http://documentos.dga.cl/SUP5426.pdf (accessed on 15 January 2020).

31. Productos grillados CR2MET. Available online: http://www.cr2.cl/datos-productos-grillados/ (accessed on 28 January 2020).

32. Alvarez-Garreton, C.; Mendoza, P.A.; Boisier, J.P.; Addor, N.; Galleguillos, M.; Zambrano-Bigiarini, M.; Lara, A.; Puelma, C.; Cortes, G.; Garreaud, R.; et al. The CAMELS-CL dataset: Catchment attributes and meteorology for large sample studies-Chile dataset. Hydrol. Earth Syst. Sci. 2018, 22, 5817-5846. [CrossRef]

33. Fritts, H.C. Tree Rings and Climate; Elsevier: London, UK, 1976. [CrossRef]

34. Cook, E.R.; Briffa, K.R.; Jones, P.D. Spatial regression methods in dendroclimatology: A review and comparison of two techniques. Int. J. Climatol. 1994, 14, 379-402. [CrossRef]

35. Weisberg, S. Applied Linear Regression; Wiley: Hoboken, NJ, USA, 1985.

36. Ostrom, C.W. Time Series Analysis: Regression Techniques; Sage: Newcastle upon Tyne, UK, 1990; Volume 9.

37. Sauchyn, D.; Vanstone, J.; Perez-Valdivia, C. Modes and Forcing of Hydroclimatic Variability in the Upper North Saskatchewan River Basin Since 1063. Can. Water Resour. J. 2011, 36, 205-217. [CrossRef]

38. Muñoz, A.A.; González-Reyes, A.; Lara, A.; Sauchyn, D.; Christie, D.; Puchi, P.; Urrutia-Jalabert, R.; Toledo-Guerrero, I.; Aguilera-Betti, I.; Mundo, I.; et al. Streamflow variability in the Chilean Temperate-Mediterranean climate transition $\left(35^{\circ} \mathrm{S}-42^{\circ} \mathrm{S}\right)$ during the last 400 years inferred from tree-ring records. Clim. Dyn. 2016, 47, 4051-4066. [CrossRef]

39. Cowling, A.; Hall, P.; Phillips, M.J. Bootstrap Confidence Regions for the Intensity of a Poisson Point Process. J. Am. Stat. Assoc. 1996, 91, 1516-1524. [CrossRef]

40. R Core Team. R: A Language and Environment for Statistical Computing; R Foundation for Statistical Computing: Vienna, Austria, 2019. Available online: https://www.R-project.org/ (accessed on 20 December 2019).

41. Mann, M.E.; Lees, J.M. Robust estimation of background noise and signal detection in climatic time series. Clim. Change 1996, 33, 409-445. [CrossRef]

42. Gorelick, N.; Hancher, M.; Dixon, M.; Ilyushchenko, S.; Thau, D.; Moore, R. Google Earth Engine: Planetary-scale geospatial analysis for everyone. Remote Sens. Environ. 2017, 202, 18-27. [CrossRef]

43. USGS Earth Explorer Portal. Available online: https://earthexplorer.usgs.gov/ (accessed on 15 November 2019).

44. McFeeters, S.K. The use of the Normalized Difference Water Index (NDWI) in the delineation of open water features. Int. J. Remote Sens. 1996, 17, 1425-1432. [CrossRef]

45. Mundo, I.A.; Masiokas, M.H.; Villalba, R.; Morales, M.S.; Neukom, R.; Le Quesne, C.; Urrutia, R.B.; Lara, A. Multi-century tree-ring based reconstruction of the Neuquén River streamflow, northern Patagonia, Argentina. Clim. Past 2012, 8, 815-829. [CrossRef]

46. Lara, A.; Villalba, R.; Urrutia, R. A 400-year tree-ring record of the Puelo River summer-fall streamflow in the Valdivian Rainforest eco-region, Chile. Clim. Chang. 2008, 86, 331-356. [CrossRef]

47. Lara, A.; Bahamondez, A.; González-Reyes, A.; Muñoz, A.A.; Cuq, E.; Ruiz-Gómez, C. Reconstructing streamflow variation of the Baker River from tree-rings in Northern Patagonia since 1765. J. Hydrol. 2015, 529, 511-523. [CrossRef]

48. Urrutia, R.B.; Lara, A.; Villalba, R.; Christie, D.A.; Le Quesne, C.; Cuq, A. Multicentury tree ring reconstruction of annual streamflow for the Maule River watershed in south central Chile. Water Resour. Res. 2011, 47, W06527. [CrossRef]

49. Ferrero, M.E.; Villalba, R.; De Membiela, M.; Ferri Hidalgo, L.; Luckman, B.H. Tree-ring based reconstruction of Río Bermejo streamflow in subtropical South America. J. Hydrol. 2015, 525, 572-584. [CrossRef]

50. Barria, P.; Peel, M.C.; Walsh, K.J.E.; Muñoz, A. The first 300-year streamflow reconstruction of a high-elevation river in Chile using tree rings. Int. J. Climatol. 2018, 38, 436-451. [CrossRef]

51. Fernández, A.; Muñoz, A.; González-Reyes, Á.; Aguilera-Betti, I.; Toledo, I.; Puchi, P.; Sauchyn, D.; Crespo, S.; Frene, C.; Mundo, I.; et al. Dendrohydrology and water resources management in south-central Chile: Lessons from the Río Imperial streamflow reconstruction. Hydrol. Earth Syst. Sci. 2018, 22, 2921-2935. [CrossRef]

52. Fritts, H.C. Reconstructing Large-Scale Climatic Patterns from Tree-Ring Data; University of Arizona Press: Tucson, AZ, USA, 1991.

53. Hughes, M.K.; Swetnam, T.W.; Diaz, H.F. (Eds.) Dendroclimatology. In Developments in Paleoenvironmental Research; Springer: Berlin, Germany, 2011. [CrossRef] 
54. González-Reyes, Á.; McPhee, J.; Christie, D.A.; Le Quesne, C.; Szejner, P.; Masiokas, M.H.; Villalba, R.; Muñoz, A.A.; Crespo, S. Spatiotemporal Variations in Hydroclimate across the Mediterranean Andes $\left(30^{\circ}-37^{\circ} \mathrm{S}\right)$ since the Early Twentieth Century. J. Hydrometeorol. 2017, 18, 1929-1942. [CrossRef]

55. Le Quesne, C.; Stahle, D.W.; Cleaveland, M.K.; Therrell, M.D.; Aravena, J.C.; Barichivich, J. Ancient Austrocedrus Tree-Ring Chronologies Used to Reconstruct Central Chile Precipitation Variability from a.d. 1200 to 2000. J. Clim. 2006, 19, 5731-5744. [CrossRef]

56. Le Quesne, C.; Acuña, C.; Boninsegna, J.A.; Rivera, A.; Barichivich, J. Long-term glacier variations in the Central Andes of Argentina and Chile, inferred from historical records and tree-ring reconstructed precipitation. Palaeogeogr. Palaeoclimatol. Palaeoecol. 2009, 281, 334-344. [CrossRef]

57. Masiokas, M.H.; Cara, L.; Villalba, R.; Pitte, P.; Luckman, B.H.; Toum, E.; Christie, D.A.; Le Quesne, C.; Mauget, S. Streamflow variations across the Andes $\left(18^{\circ}-55^{\circ} \mathrm{S}\right)$ during the instrumental era. Sci. Rep. 2019, 9, 1-13. [CrossRef] [PubMed]

58. Saavedra, F.A.; Kampf, S.K.; Fassnacht, S.R.; Sibold, J.S. Changes in Andes snow cover from MODIS data, 2000-2016. Cryosphere 2018, 12, 1027-1046. [CrossRef]

59. Saavedra, F.A. University of Playa Ancha, Valparaíso, Chile. Personal communication, 2019.

60. Osses Sandoval, P. Impacto de la megasequía 2010-2015 Sobre los Niveles de Aguas Subterráneas en las Cuencas de los ríos Petorca y La Ligua, Región de Valparaíso. Bachelor's Thesis, Pontifical Catholic University of Valparaíso, Valparaíso, Chile, November 2019.

61. Vilches, C. Water Resources Office, Municipality of Petorca, Chile. Personal communication, 2020.

62. Valdés-Pineda, R.; García-Chevesich, P.; Valdés, J.B.; Pizarro-Tapia, R. The First Drying Lake in Chile: Causes and Recovery Options. Water 2020, 12, 290. [CrossRef]

63. Chávez, R.O.; Pontifical Catholic University of Valparaíso, Valparaíso, Chile. Personal communication, 2020.

64. Appeal Court ruling. Protection Number-9709-2019, of the Fifth Chamber of the Court of Appeals of Valparaíso. 2019.

65. Social Water Conflicts Portal. Available online: http://www.derechoalagua.cl/mapa-de-conflictos/ (accessed on 30 January 2020).

66. Frene, C.; Molina, C.; Santibáñez, J.; Ojeda, G.; Donoso, C.; Sanzana, J.; Andrade, P.; Núñez-Ávila, M. Agua en Chile: Diagnósticos Territoriales y Propuestas para Enfrentar la Crisis; América Ltda: Santiago de Chile, Chile, 2016.

67. Donoso, G. (Ed.) Water Policy in Chile; Global Issues in Water Policy Series; Springer: Berlin, Germany, 2018; 224p, ISBN 978-3-319-76701-7.

68. Christensen, J.H.; Hewitson, B.; Busuioc, A.; Chen, A.; Gao, X.; Held, R.; Jones, R.; Kolli, R.K.; Kwon, W.K.; Laprise, R.; et al. Regional climate projections. In Climate Change, 2007: The Physical Science Basis. Contribution of Working group I to the Fourth Assessment Report of the Intergovernmental Panel on Climate Change; University Press: Cambridge, UK, 2007; Volume 11, pp. 847-940.

69. Mariotti, A.; Pan, Y.; Zeng, N.; Alessandri, A. Long-term climate change in the Mediterranean region in the midst of decadal variability. Clim. Dyn. 2015, 44, 1437-1456.

70. Polade, S.D.; Gershunov, A.; Cayan, D.R.; Dettinger, M.D.; Pierce, D.W. Precipitation in a warming world: Assessing projected hydro-climate changes in California and other Mediterranean climate regions. Sci. Rep. 2017, 7, 1-10. [CrossRef]

71. Mbow, H.O.P.; Reisinger, A.; Canadell, J.; O’Brien, P. Special Report on Climate Change, Desertification, Land Degradation, Sustainable Land Management, Food Security, and Greenhouse Gas Fluxes in Terrestrial Ecosystems (SR2); IPCC: Geneva, Switzerland, 2017.

(C) 2020 by the authors. Licensee MDPI, Basel, Switzerland. This article is an open access article distributed under the terms and conditions of the Creative Commons Attribution (CC BY) license (http://creativecommons.org/licenses/by/4.0/). 